\title{
The Research on the English Reading Teaching Mode Aiming at the Improvement of Thinking Quality
}

\section{Jinran Wu}

China West Normal University, Nanchong, Sichuan, China

\begin{abstract}
In English reading teaching, it is important and necessary to promote the development of students' thinking quality, an important element of key competence of the English subject. However, the current English reading teaching overemphasizes language knowledge input, the extraction of basic information and the application of reading strategies, but neglects the cultivation of students' thinking quality. Therefore, how to develop students' thinking quality in English reading teaching has become an important issue to be solved.
\end{abstract}

Key words: key competence; thinking quality; English reading teaching mode

\section{Research Background}

With the advent of the information age, innovative ability becomes more and more important. An article published in China Education Daily pointed out that the lack of innovative ability of Chinese students has always been a drawback of Chinese education. The students who have entered the society lack the innovative awareness, and their natural imagination could not be released, which has affected China's competitiveness in the world. Therefore, paying attention to the development of students' thinking quality, especially the development of innovative thinking, is the core project in our education. In January 2018, the English Curriculum Standard for Senior High School (2017 Edition) was officially released, clearly pointing out that the curriculum goal of senior high school English is to develop students' key competence, including language ability, cultural awareness, thinking quality and learning ability. For the first time, the thinking quality has been clearly listed as one of the elements of key competence.

Reading teaching is an important part of English teaching, and also an important way to cultivate students' thinking quality. The corpus used in English reading teaching is not only the source of students' language learning, but also the carrier of thinking cultivation. Therefore, reading teaching plays a very important role in developing students' thinking quality. However, the existing English teaching put great emphasis on superficial aspects, such as words explanation, grammar practice and so on, but neglects the process of cultivating students' thinking ability. In such a teaching mode, students' learning is shallow and superficial, with slow thinking and reading speed. Therefore, this research takes the development of students' thinking quality as the starting point and foothold, and uses English reading teaching as the carrier to explore the English reading teaching mode, aiming to improve students' thinking quality.

\section{The Concept of Thinking Quality}

Copyright (C) 2021 by author(s) and Frontier Scientific Research Publishing Inc.

This work is licensed under the Creative Commons Attribution International License (CC BY 4.0).

$\mathrm{http} / / /$ creativecommons.org/licenses/by/4.0/ 
The English Curriculum Standard for Senior High School (2017 Edition) points out that thinking quality refers to the ability and level of thinking in the aspects of logic, criticism and creativity, reflecting the mental characteristics of the key competence in English subject. The development of thinking quality helps to improve students' ability to analyze and solve problems, enable them to observe and understand the world from a cross-cultural perspective, and make correct value judgments on things. In recent years, many domestic scholars have further understood the word "thinking quality". Professor Huang Yuanzhen believes that thinking quality is not only the key ability but also the necessary character, which contains both thinking ability and thinking personality. Thinking ability is an intellectual factor, while thinking personality trait is a non intellectual factor, which is based on and transcends knowledge. Professor Chen Zehang, Wang Qiang and Qian Xiaofang believe that thinking quality refers to the individual performance in intelligence activities, especially in thinking activities, and its essence is human personality. Professor Lin Chongde believes that the components and forms of thinking quality mainly include the profundity, flexibility, creativity, criticism and agility of thinking.

\section{The Mode of English Reading Teaching Aiming at the Improvement of Thinking Quality}

\subsection{The change of teaching concept}

In the English reading teaching, the teachers should adhere to the teaching concept of "let students learn and think creatively", which is the premise of realizing the goal of developing students' thinking quality. "Let students learn" means that in classroom teaching, teachers should hand over their dominance of the classroom to students as much as possible, so that students can study actively, creatively and happily, and be masters of learning. "Let students to think creatively" emphasizes that teaching activities should stimulate students to think actively in the process of learning. In this way, students will be in an active learning position and have chances to express their views freely.

3.2 The change of English reading teaching mode

3.2.1 Stimulate students to think by asking questions

Questions design in English reading teaching is an important teaching skill. Students' thinking quality mainly includes three levels: logical thinking, critical thinking and innovative thinking. Therefore, in reading teaching, in order to improve students' thinking quality, teachers should pay attention to these three levels and design three different types of questions according to them.

The first kind of questions is put forward according to the logical context of the text, which can help students to tease out the content of the text, summarize the main points in the text, so as to improve their text analysis ability and logical reasoning ability, thus developing their logical thinking. The second kind of questions is put forward according to the theme of the text, which can guide students to pay attention to the author's views and attitudes, and make in-depth analysis and evaluation. In the process of answering such questions, students' critical thinking can be developed. The third kind of problems can be proposed for the extension and expansion of the text theme, aiming to set up new situations for students and put forward new problems for students to solve, so as to trigger students' creativity. This type of questions can also be designed according to the writing mode of the text, which aims to guide students to observe, analyze and absorb excellent text writing mode, so that they can apply this kind of writing mode to their writing.

The passage"What's in a name?" can be taken as an example. This passage is chosen from the unit 4 "History and traditions" in senior high English book (PER version). It briefly tells us the historical and cultural story of Britain behind the name of "the United Kingdom". When guiding students to learn this article, teachers can design three kinds of different problems according to the three levels of students' thinking quality.

The first type is proposed according to the logical context of the article, which aims to help students obtain the factual information about Britain in the article and make a summary. The questions can be designed as follows: 
A. Do you know the full name of the United Kingdom?

B. According to the map, what are the four countries of the United Kingdom?

C. What's the history about the UK in the name of "The United Kingdom of Great Britain and Northern Ireland"?

The sub-questions:

a. when did the Romans arrived in the UK?

b. In the 11th century, what happened?

c. In the 16th century, what happened?

d. When was the nearby country of Wales joined to the Kingdom of England?

The second type is put forward according to the theme meaning of the text, which aims to guide students to pay attention to the author's point of view or attitude and conduct in-depth analysis and evaluation. The questions can be designed as follows:

A. According to the author, what are two chief advantages of studying the history of a country?

$B$. Why does the author say that the capital London is a great place to travel?

C. Why is it important to study the history and culture of a country before visiting it? Do you agree with the author's opinions?

The third type can be put forward not only according to the extension and expansion of the theme of the text, but also according to the writing style of the text, which aims at developing students' innovative thinking. According to the extension and expansion of the theme of the text, questions can be designed as follows:

A. What important things should visitors know before they come to China?

B. What is the history in the name of Beijing, the capital of China?

According to the writing style of the text, questions can be designed as follows:

In the article, the author briefly introduces the history of the UK to us according to a timeline, can you briefly introduce the history of China to some foreigners according to a timeline? Please write an article about the history of China after class.

\subsubsection{Stimulate students to think by using mind maps}

When students answer questions about the logical context of the article, if teachers can guide students to tease out the context of the text by using a mind map, they can better understand the logic of the article. For example, when teasing out the information about British history in this article, students can use a timetable. See Table 1 for details.

Table 1. Timetable

\begin{tabular}{|c|c|l|}
\hline When? & What happened? & \multicolumn{1}{|c|}{ What changed? } \\
\hline 1th century & Romans arrived in the UK & $\begin{array}{l}\text { Made their great achievements including } \\
\text { building towns and roads }\end{array}$ \\
\hline 5th century & Anglo-Saxons came & $\begin{array}{l}\text { Introduced the beginnings of the English } \\
\text { language and changed the way people built } \\
\text { houses }\end{array}$ \\
\hline 8th century & Vikings came & $\begin{array}{l}\text { Left behind lots of new vocabulary and the } \\
\text { names of many locations }\end{array}$ \\
\hline 11th century & $\ldots$ & \multicolumn{1}{|c}{$\cdots$} \\
\hline
\end{tabular}

3.2.3 The change of assessment system

Mid-term and final examination are often regarded as the main form of assessing students academic performance. 
However, these assessment methods will make most students only pay attention to their scores, and ignore whether their ability has been improved, which will cause "high score, low ability" to a certain extent. In the teaching process, teachers should adopt formative assessment, emphasizing students' learning process, including classroom discussion, learning achievement display and so on. In addition, self-assessment and peer assessment should also be advocated. And teachers should also pay attention to the reading class itself is a class of divergent thinking. Teachers should respect students' thinking achievements, encourage students to imagine and express their ideas freely.

\section{Conclusions}

In reading teaching, teachers should always adhere to the teaching ideas of "let students learn and think creatively". In classroom teaching, teachers should design questions that are conducive to the development of students' thinking quality, guide students to study independently in the process of answering questions. In these ways, the goal of the development of students' thinking quality could be achieved.

\section{Conflicts of Interest}

The author declares no conflicts of interest regarding the publication of this paper.

\section{References}

[1] Fan Y.G. (2012). There is No Need to Avoid the Lack of Innovation Ability of Chinese students. Shaanxi Education (Administration), (11): 72.

[2] Ge B.F. and Hong L. (2018). Research on English Reading Teaching Aiming at Improving Thinking Quality. Curriculum, Teaching Materials and Teaching Methods, (11): 110-115.

[3] Ministry of Education. (2018). English Curriculum Standards for Senior High Schools (2017). People's Education Press, Beijing.

[4] Huang Y.Z. (2017). Teaching English for Thought: from "Necessity" to "Possibility". Foreign Language Teaching in Primary and Secondary Schools (Middle School), (04): 1-2.

[5] Chen M.L. (2016). On the Connotation and Cultivation of Key Competences in English Subject. Educational Review, (8): 131-133.

[6] Lin C.D. (2005). Training the Thinking Quality is the Breakthrough of Developing Intelligence. Journal of the National College of Education and Administration, (09): 25-30+36. 